\title{
Correction to: Identification of soybean Bradyrhizobium strains used in commercial inoculants in Brazil by MALDI-TOF mass spectrometry
}

\section{Lucas Rolim ${ }^{1}$ - Thaís Ribeiro Santiago ${ }^{2}$ - Fábio Bueno dos Reis Junior ${ }^{3} \cdot$ leda de Carvalho Mendes ${ }^{3}$. Helson Mario Martins do Vale ${ }^{1}$. Mariangela Hungria ${ }^{4}$. Luciano Paulino Silva ${ }^{1,2}$}

Published online: 14 August 2019

(C) Sociedade Brasileira de Microbiologia 2019

Correction to: Brazilian Journal of Microbiology https://doi.org/10.1007/s42770-019-00104-3

The original version of this article unfortunately contained a mistake. The presentation of Fig. 1 was incorrect. The correct version is given below.
The online version of the original article can be found at https://oi.org/ 10.1007/s42770-019-00104-3

Luciano Paulino Silva

luciano.paulino@embrapa.br

Lucas Rolim

roliml@gmail.com

Thaís Ribeiro Santiago

tatasantiago@gmail.com

Fábio Bueno dos Reis Junior

fabio.reis@embrapa.br

Ieda de Carvalho Mendes

ieda.mendes@embrapa.br

Helson Mario Martins do Vale

helson@unb.br
Mariangela Hungria

mariangela.hungria@embrapa.br

1 Universidade de Brasilia (UnB), Brasília, Distrito Federal 70910-900, Brazil

Embrapa Recursos Genéticos e Biotecnologia, C.P. 02372, Brasília, Distrito Federal 70770-917, Brazil

3 Embrapa Cerrados, C.P. 08223, Planaltina, Distrito Federal 73310-970, Brazil

4 Embrapa Soja, C.P. 231, Londrina, Paraná 86001-970, Brazil 

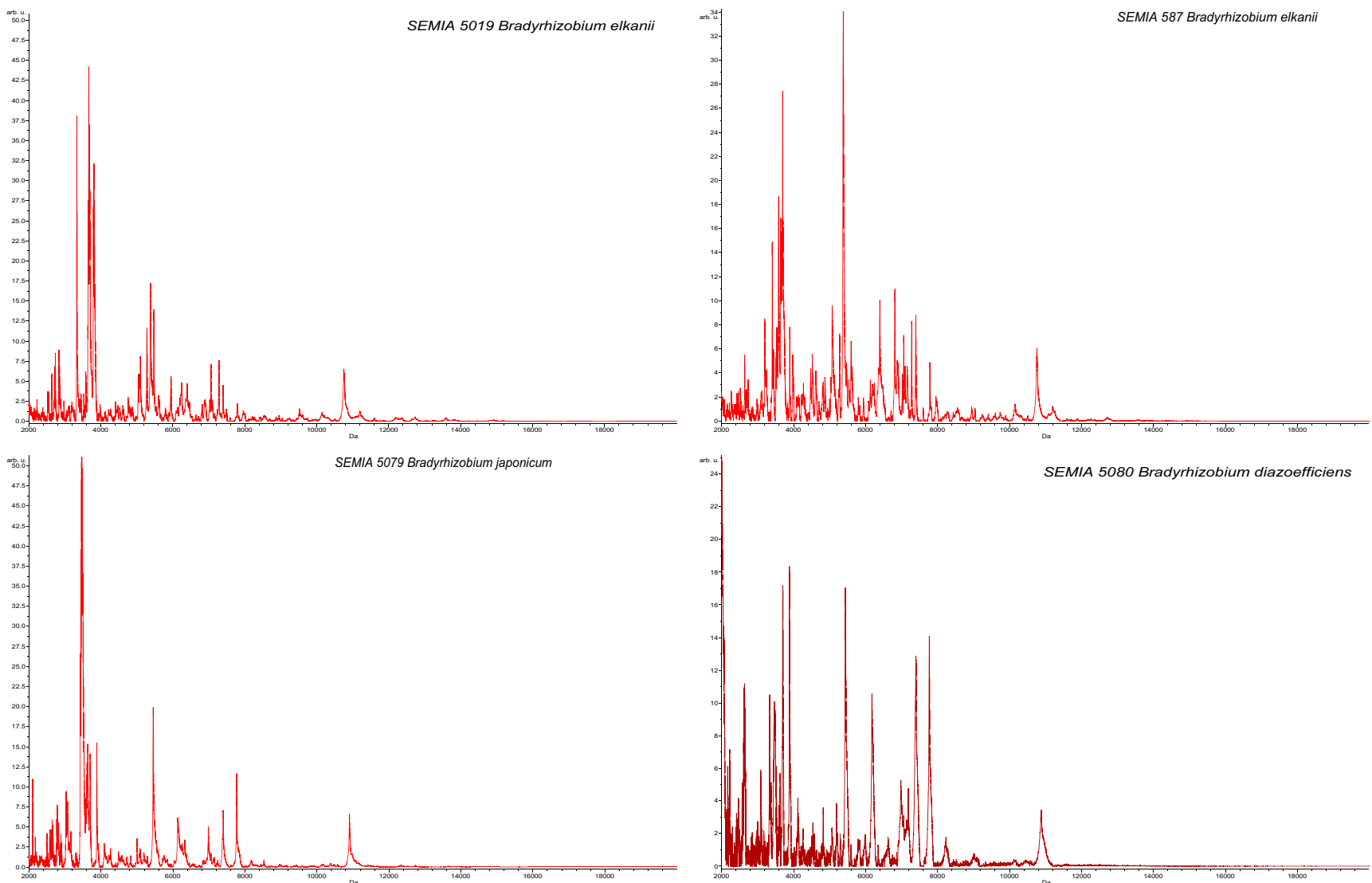

Fig. 1 Representative standard mass spectra of the four elite strains obtained from the average of 24 distinct acquisitions

Publisher's note Springer Nature remains neutral with regard to jurisdictional claims in published maps and institutional affiliations. 